\title{
NOTES
}

\section{CORPORATE ATTORNEY-CLIENT PRIVILEGES AND WORK- PRODUCT PROTECTIONS SHOULD ABSOLUTELY BE PRESERVED}

\author{
Jennifer M. Gardner
}

\author{
INTRODUCTION
}

\begin{abstract}
In order to promote freedom of consultation of legal advisers by clients, the apprehension of compelled disclosure by the legal advisers must be removed; hence the law must prohibit such disclosure except on the client's consent. ${ }^{1}$

Looking back at the reason of the privilege, it is seen to secure the client's freedom of mind in committing his affairs to the attorney's knowledge. It is designed to influence him when he may be hesitating between the positive action of disclosure and the inaction of secrecy. ${ }^{2}$
\end{abstract}

The attorney-client privilege is one of the oldest and most basic tenets of American common law. ${ }^{3}$ Over the years, however, this privilege has eroded away as it applies to corporations. Beginning in 1999 with the promulgation of a memorandum issued by then-Deputy Attorney General Eric H. Holder

* $\quad$ Editor in Chief, University of Pittsburgh Law Review; J.D., University of Pittsburgh School of Law, 2008; B.S., The Ohio State University, 2000. The author wishes to thank Professor Sandra Jordan of the University of Pittsburgh School of Law for her guidance on this topic and for her help in preparation of this Note.

1. John Henry Wigmore, 8 Wigmore, Evidence $§ 2291$ (McNaughton rev. 1961).

2. Id. at $\S 2307$.

3. Upjohn Co. v. United States, 449 U.S. 383, 389 (1981) (citing John Henry Wigmore, 8 WigMORE, EVIDENCE $§ 2290$ (McNaughton rev. 1961)). 
(the Holder Memo), ${ }^{4}$ the Department of Justice has consistently pursued a policy of "compelled waiver" with regard to corporations. This Department policy has been repeatedly reaffirmed over the years in subsequent memoranda from Deputy Attorney General Larry D. Thompson (the Thompson Memo), ${ }_{5}^{5}$ Acting Deputy Attorney General Robert D. McCallum, Jr. (the McCallum Memo), ${ }^{6}$ and Deputy Attorney General Paul J. McNulty (the McNulty Memo). ${ }^{7}$

According to the Department of Justice policy, a corporation should be willing to waive its attorney-client privilege and its work-product protection in order to show that it is cooperating with an investigation. ${ }^{8}$ A prosecutor is specifically instructed to consider the corporation's willingness to waive these privileges and protections when that prosecutor is deciding whether or not to charge the corporation. ${ }^{9}$ This process has come to be known as "compelled waiver" because a corporation is "compelled" to accede to a waiver request in order to show the cooperation necessary to avoid indictment. Compelled waiver has become a very real concern to corporations and to the legal profession because it significantly reduces the protections previously afforded by the attorney-client privilege and the work-product protection. ${ }^{10}$

Not only does compelled waiver infringe upon a corporation's attorneyclient privilege and work-product protection in the primary investigation, but it also causes a corporation to forfeit the privilege and protection as to all other adversaries, including civil litigants. Once the corporation has agreed to

4. Memorandum from Deputy Att'y Gen. Eric H. Holder to All Component Heads and United States Attorneys, Bringing Criminal Charges Against Corps. (June 16, 1999), available at http://www.usdoj.gov/criminal/fraud/docs/reports/1999/chargingcorps.html, reprinted in 66 CRIM. L. REP. 189 (1999) [hereinafter Holder Memo].

5. Memorandum from Deputy Att'y Gen. Larry D. Thompson to Heads of Dep't Components and United States Attorneys, Principles of Fed. Prosecution of Bus. Orgs. (Jan. 20, 2003), available at http://www.usdoj.gov/dag/cftf/corporate_guidelines.htm, reprinted in 72 CRIM L. REP. (BNA) 481 (2003) [hereinafter Thompson Memo].

6. Memorandum from Acting Deputy Att'y Gen. Robert D. McCallum, Jr. to Heads of Dep't Components and United States Attorneys, Waiver of Corporate Attorney-Client and Work Product Protection (Oct. 21, 2005), available at http://www.corporatecrimereporter.com/documents/ AttorneyClientWaiverMemo.pdf [hereinafter McCallum Memo].

7. Memorandum from Deputy Att'y Gen. Paul J. McNulty to Heads of Dep't Components and United States Attorneys, Principles of Fed. Prosecution of Bus. Orgs., http://www.usdoj.gov/ dag/speeches/2006/mcnulty_memo.pdf (last visited Aug. 14, 2008) [hereinafter McNulty Memo].

8. See, e.g., Holder Memo, supra note 4, § VI.A; McNulty Memo, supra note 7, § VII.B.2.

9. McNulty Memo, supra note 7, § III.A.4, § VII.B.2.

10. See, e.g., Statement of Dick Thornburgh, Counsel, Kirkpatrick \& Lockhart Nicholson Graham LLP and Former Att'y Gen. of the United States, Before the U.S. Sentencing Comm'n Pub. Meeting Regarding Chapter Eight Waiver of Attorney-Client Privilege \& Work Product Protections (Nov. 15, 2005), available at http://www.ussc.gov/corp/11_15_05/Thornburgh.pdf. 
waive its privilege or its protection, it cannot reclaim either against future adversaries. In 1977, the Eighth Circuit introduced a concept of limited, or selective, waiver that attempted to ameliorate this concern. ${ }^{11}$ The selective waiver doctrine allowed a corporation to continue to claim attorney-client privilege or work-product protection for documents that it revealed to the government in the course of a criminal investigation. However, as I shall discuss in this Note, this doctrine has been systematically rejected by all other circuits considering the issue. Furthermore, in most circuits, the privilege is considered waived in its entirety even if waived in response to governmental compulsion. ${ }^{12}$

In January 2007, Senator Arlen Specter introduced the Attorney-Client Privilege Protection Act (the ACPPA) in the Senate in an attempt to safeguard the attorney-client privilege and work-product protection. ${ }^{13}$ If passed, the ACPPA will make it illegal for United States Attorneys to condition any charging decision upon waiver of a corporation's attorney-client privilege or work-product protection. ${ }^{14}$ This Act would seem to restore the attorney-client privilege and the work-product protection to their previous statuses in the corporate context. However, the ACPPA does not contain any remedy provisions and so it remains unclear what consequences will accrue in the event that the Act is violated. Corporations must still be on guard and actively protect their privileges because it is possible that the ACPPA will offer little protection once waiver has been obtained by a U.S. Attorney.

In Part I of this Note, I will discuss the history and policy of the attorneyclient privilege and the work-product protection. Part II will explore the history of the Department of Justice policy of compelling corporations to waive their privileges and protections. Part III will discuss the evolution of selective waiver and its limited ability to correct the harms caused by

11. Diversified Indus., Inc. v. Meredith, 572 F.2d 596, 611 (8th Cir. 1978).

12. See In re Qwest Commc'ns Int'l Inc., 450 F.3d 1179 (10th Cir. 2006); In re Columbia/HCA Healthcare Corp., 293 F.3d 289 (6th Cir. 2002); United States v. Mass. Inst. of Tech., 129 F.3d 681 (1st Cir. 1997); Genentech, Inc. v. U.S. ITC, 122 F.3d 1409 (Fed. Cir. 1997); In re Steinhardt Partners, L.P., 9 F.3d 230 (2d Cir. 1993); Westinghouse Elec. Corp. v. Republic of the Phil., 951 F.2d 1414 (3d Cir. 1991); In re Martin Marietta Corp., 856 F.2d 619 (4th Cir. 1988); Permian Corp. v. United States, 665 F.2d 1214 (D.C. Cir. 1981).

13. Attorney-Client Privilege Protection Act of 2007, S. 186, 110th Cong. (2007) [hereinafter ACPPA]. A companion bill was introduced in the House of Representatives by Representative Robert Scott on July 12, 2007, and was passed on November 13, 2007. Attorney-Client Privilege Protection Act of 2007, H.R. 3013, 110th Cong. (2007). However, the Senate bill appears to be stalled in the Senate despite significant legislative and executive support. See, e.g., Lynnley Browning, Bill to Protect Companies in Inquiries Adds Support, N.Y. TIMEs, June 23, 2008, at C1.

14. S. 186 at $\S 3(b)$. 
compelled waivers. Part IV will evaluate the Attorney-Client Privilege Protection Act and its ability to protect a corporation from issues of compelled waiver. Part V discusses the possible remedies for violations of the ACPPA. This Note concludes that without stated remedies, it is unlikely that the ACPPA will provide a corporation with significant protection from compelled waiver and advises corporations to continue to take an active approach to guarding their attorney-client privilege and work-product protection.

\section{The History and Policy of the Attorney-Client Privilege And the Work-Product Protection}

\section{A. The Attorney-Client Privilege}

"The attorney-client privilege is the oldest of the privileges for confidential communications known to the common law." 15 The primary function of the privilege "is to encourage full and frank communication between attorneys and their clients and thereby promote broader public interests in the observance of law and administration of justice." 16 The law recognizes this privilege because of the important role that a fully informed lawyer plays in guiding a corporate client in its compliance efforts. ${ }^{17}$ Narrowing the scope of this privilege "not only makes it difficult for corporate attorneys to formulate sound advice when their client is faced with a specific legal problem but also threatens to limit the valuable efforts of corporate counsel to ensure their client's compliance with the law." ${ }^{18}$ In the absence of the privilege, "the client would be reluctant to confide in his lawyer and it would be difficult to obtain fully informed legal advice." 19

Privileges keep relevant evidence from the factfinder. ${ }^{20}$ Therefore, the attorney-client privilege is narrowly construed and only applies to "those disclosures [ ] necessary to obtain informed legal advice [ ] which might not have been made absent the privilege." ${ }^{21}$ For example, a pre-existing and discoverable document will not become privileged when the client shares it with an attorney because the privilege is not necessary to encourage the client

\footnotetext{
15. Upjohn Co. v. United States, 449 U.S. 383, 389 (1981) (citing John Henry Wigmore, 8 Wigmore, EVIDENCE $\S 2290$ (McNaughton rev. 1961)).

16. Id.

17. $I d$.

18. Id. at 392.

19. Fisher v. United States, 425 U.S. 391, 403 (1976).

20. Id.

21. Id.
} 
to share the document. ${ }^{22}$ However, a statement made to an attorney in search of legal advice is privileged because denial of the privilege would make the client less likely to make the statement. ${ }^{23}$ This privilege has been held to apply to corporations as well as individuals. ${ }^{24}$

\section{B. The Work-Product Protection}

[I]t is essential that a lawyer work with a certain degree of privacy, free from unnecessary intrusion by opposing parties and their counsel. Proper preparation of a client's case demands that he assemble information, sift what he considers to be the relevant from the irrelevant facts, prepare his legal theories and plan his strategy without undue and needless interference. That is the historical and the necessary way in which lawyers act within the framework of our system of jurisprudence to promote justice and to protect their clients' interests. This work is reflected, of course, in interviews, statements, memoranda, correspondence, briefs, mental impressions, personal beliefs, and countless other tangible and intangible ways - aptly though roughly termed by the Circuit Court of Appeals in this case as the "work product of the lawyer." Were such materials open to opposing counsel on mere demand, much of what is now put down in writing would remain unwritten. An attorney's thoughts, heretofore inviolate, would not be his own. Inefficiency, unfairness and sharp practices would inevitably develop in the giving of legal advice and in the preparation of cases for trial. The effect on the legal profession would be demoralizing. And the interests of the clients and the cause of justice would be poorly served. ${ }^{25}$

The concept of protecting an attorney's work-product was developed more recently. ${ }^{26}$ Federal Rule of Civil Procedure 26(b)(3) only allows an adverse party to obtain an attorney's work-product "upon a showing that the party seeking discovery has substantial need of the materials in the preparation of the party's case and that the party is unable without undue hardship to obtain the substantial equivalent of the materials by other means." Even upon such a showing, the "mental impressions, conclusions, opinions, or legal theories of an attorney or other representative of the party concerning the litigation" are protected from disclosure. ${ }^{27}$ The purposes for this protection are twofold: (1) without this protection, "much of what is now put down in writing would remain unwritten" leading to inefficiency and reduced service

22. Id. at 404 .

23. $I d$.

24. Upjohn Co. v. United States, 449 U.S. 383, 390 (1981).

25. Hickman v. Taylor, 329 U.S. 495, 510-11 (1947).

26. Work-product protection was first recognized by the Supreme Court in Hickman, 329 U.S. at 495, and was later codified in Federal Rule of Civil Procedure 26(b)(3).

27. $I d$. 
for the client, and (2) the legal profession would be harmed as "unfairness and sharp practices" would develop and attorneys would become "demoraliz[ed]." ${ }^{28}$ Like recognition of attorney-client privilege, recognition of work-product protection best serves "the interests of the clients and the cause of justice." 29

\section{Compelled Waiver and Measuring Corporate Cooperation}

A. The Holder and Thompson Memos: Requiring Waiver of the AttorneyClient Privilege and the Work-Product Protection in Exchange for Cooperation Credit

In June 1999, Deputy Attorney General Eric Holder Jr. issued a memo to all United States Attorneys, commonly referred to as the "Holder Memo." 30 The purpose of this memo was to establish guidelines to assist prosecutors in deciding when to charge a corporation. The memo set out eight factors for a prosecutor to consider "in reaching a decision as to the proper treatment of a corporate target." "31 These factors guide a prosecutor "[i]n conducting an investigation, determining whether to bring charges, and negotiating plea agreements." ${ }^{32}$ The purpose of these factors is to "ensure that the general purposes of the criminal law - assurance of warranted punishment, deterrence of further criminal conduct, protection of the public from dangerous and fraudulent conduct, rehabilitation of offenders, and restitution for victims and affected communities - are adequately met." ${ }^{\text {33 }}$

One of the eight factors that the Holder Memo instructs prosecutors to consider is " $[t]$ he corporation's timely and voluntary disclosure of wrongdoing and its willingness to cooperate in the investigation of its agents, including, if necessary, the waiver of the corporate attorney-client and work product privileges." ${ }^{" 34}$ The memo highlights the significant benefits that can accrue to the government when a target has been convinced to waive these protections: "Such waivers permit the government to obtain statements of possible witnesses, subjects, and targets, without having to negotiate individual

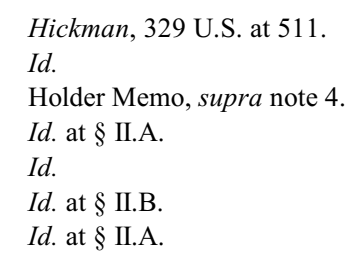


cooperation or immunity agreements. In addition, they are often critical in enabling the government to evaluate the completeness of a corporation's voluntary disclosure and cooperation." ${ }^{35}$

In January 2003, Deputy Attorney General Larry D. Thompson released a revised version of the Holder Memo, commonly referred to as the "Thompson Memo." ${ }^{36}$ The purpose of the revised memo was to "increase[ ] emphasis on and scrutiny of the authenticity of a corporation's cooperation." ${ }^{37}$ This memo identified nine factors for evaluating a corporation's level of cooperation, but still included a corporation's waiver of its attorney-client privilege and work-product protections as a factor in making charging decisions. ${ }^{38}$ Footnotes in both memos suggested that waivers should only be requested with respect to extraneous matters and should not be sought "with respect to communications and work product related to advice concerning the government's criminal investigation." ${ }^{39}$

These documents transformed the concept of waiver into something that was required, rather than something that was beneficial. The now-infamous Arthur Andersen incident provides a vivid example of the danger of not cooperating with the government. ${ }^{40}$ When an indictment has the potential effect of annihilating a corporation, there is a considerable amount of pressure to do whatever the government asks in order to avoid indictment. If the government considers waiver of attorney-client privilege and work-product protection as one of only a few factors in deciding whether or not to indict a corporation, the pressure on the corporation to comply is significant.

35. Id. at $\S$ VI.B.

36. Thompson Memo, supra note 5.

37. Id. at Introduction.

38. Id. at $\S$ II.A.

39. Holder Memo, supra note 4, at n.2; Thompson Memo, supra note 5, at n.3.

40. See generally Elizabeth K. Ainslie, Essay: Indicting Corporations Revisited: Lessons of the Arthur Andersen Prosecution, 43 AM. CRIM. L. REV. 107 (2006) (discussing the dramatic consequences of the criminal indictment of Arthur Andersen). See also White Collar Enforcement: Attorney-Client Privilege and Corporate Waivers: Hearing Before the Subcomm. on Crime, Terrorism, and Homeland Security of the H. Comm. on the Judiciary, 109th Cong. 17 (2006) (statement of Thomas J. Donohue, President \& CEO, U.S. Chamber of Commerce) (Speaking on behalf of the Coalition to Preserve the Attorney Client Privilege, Mr. Donahue stated that not only does "[a] company that refuses to waive its privilege risk[] being labeled as uncooperative, which all but guarantees that it will not get a settlement or receive, if it needs to, leniency in sentencing of fines," but "[ $t]$ he uncooperative label can severely damage a company's brand, its shareholder value, their relationship with suppliers and customers, and their very ability to survive."). 
B. The McCallum Memo: Emphasizing the Government's Need for Waiver and Encouraging an Official Request Process

In October 2005, Acting Deputy Attorney General Robert D. McCallum, Jr. released a memo that further entrenched the Department's policy of compelling waiver. ${ }^{41}$ Commonly referred to as the "McCallum Memo," this document re-emphasized the importance of the Thompson Memo and instructed each U.S. Attorney's Office to establish written policies related to waiver requests. ${ }^{42}$ It authorized U.S. Attorneys to use their discretion "to seek timely, complete, and accurate information from business organizations."

In March 2006, Mr. McCallum spoke to the Judiciary Committee's Subcommittee on Crime, Terrorism, and Homeland Security concerning the waiver requests. ${ }^{44}$ In that speech, McCallum emphasized the American political war on corporate fraud. ${ }^{45}$ He highlighted the successes of the U.S. Attorneys in convicting corporate fraud offenders, and said that "[m]uch of our success depends on our ability to secure cooperation." ${ }^{\prime 46}$ This cooperation, he noted, includes securing waiver of attorney-client privilege and workproduct protection. ${ }^{47}$ Although McCallum claimed to have an utmost level of respect for the purposes of the attorney-client privilege, he declared that these privileges run counter to the Department's ability "to prosecute in a timely and efficient manner." ${ }^{48} \mathrm{He}$ stated that he believed the Thompson Memo creates an appropriate balance between "the legitimate interests furthered by the privilege" and the need for "rigorous enforcement of the laws supporting ethical standards of conduct." $" 49$

McCallum gave four reasons detailing why the requested waiver policy did not violate privilege concerns. First, waiver is only one part of cooperation, and cooperation is not the only factor considered when deciding whether to charge a corporation. ${ }^{50}$ Second, waiver is only sought when there

41. See McCallum Memo, supra note 6.

42. Id.

43. $I d$.

44. White Collar Enforcement: Attorney-Client Privilege and Corporate Waivers: Hearing Before the Subcomm. on Crime, Terrorism, and Homeland Security of the H. Comm. on the Judiciary, 109th Cong. 5 (2006) (statement of Robert D. McCallum, Jr., Associate Attorney General) [hereinafter March 2006 McCallum Statement].

45. Id. at 9 .

46. Id.

47. $I d$.

48. Id. at $9-10$.

49. Id. at 9 .

50. $I d$. 
is "a need for timely, complete, and accurate information" and then only with supervisory approval. ${ }^{51}$ Third, waiver requests will not deter corporations from conducting internal investigations because "responsible management" has a duty to the shareholders to continue to conduct "timely internal investigation[s]." ${ }^{, 52}$ Finally, the harm of these waivers would be reduced by the proposed Federal Rule of Evidence 502(c)'s creation of "selective waiver." 53

\section{The Public Response and the Alleged Harm to Corporations and the Corporate Legal Community}

Despite McCallum's assurances that waivers are not routinely sought, there is evidence that runs counter to that assertion. In November 2005, Dick Thornburgh, counsel at Kirkpatrick \& Lockhart Nicholson Graham LLP ${ }^{54}$ and former U.S. Attorney General, testified before the U.S. Sentencing Commission. ${ }^{55}$ He testified that the white-collar criminal defense attorneys at his firm "now encounter waiver requests in virtually every organizational criminal case in which they are involved" and that "waiver has become a standard expectation of federal prosecutors. ${ }^{.56}$ Governor Thornburgh told the committee that the McCallum Memo "strikes a rather defiant tone that can only embolden prosecutors." ${ }^{.57}$ His suggestion to the committee was that protection of the attorney-client privilege and attorney work-product should be restored because these protections are "a fair limitation on prosecutors, who have extraordinary powers to gather information for themselves." 58

In March 2006, Kent Wicker, law professor at the University of Louisville and a former Assistant U.S. Attorney, testified to the Sentencing Commission on behalf of the National Association of Criminal and Defense Lawyers. ${ }^{59}$ He told the story of representing an officer of a company that felt

\section{Id}

52. Id. at 11 .

53. Id. The proposed Federal Rule of Evidence 502(c) referred to here was later omitted from the Rule as presented to Congress. See infra Section III.B.

54. Now Kirkpatrick \& Lockhart Preston Gates Ellis LLP.

55. Statement of Dick Thornburgh, Counsel, Kirkpatrick \& Lockhart Nicholson Graham LLP and Former Att'y Gen. of the United States, Before the U.S. Sentencing Comm'n Pub. Meeting Regarding Chapter Eight Waiver of Attorney-Client Privilege \& Work Product Protections (Nov. 15, 2005), available at http://www.ussc.gov/corp/11_15_05/Thornburgh.pdf.

56. $I d$. at 2 .

57. Id. at 4 .

58. Id.

59. Hearing Before the United States Sentencing Commission (Mar. 15, 2006) (statement of Kent Wicker, National Association of Criminal Defense Lawyers), available at http://www.ussc.gov/ 
compelled to waive the privilege "because they were afraid they wouldn't be able to avoid indictment or to obtain reduction for acceptance of responsibility or lack of culpability if they refused to waive the privilege." ${ }^{60}$ This situation adversely impacted the defense of the individual and prevented the company from entering into a joint defense agreement with the officer. ${ }^{61}$ In another incident, a corporation was compelled to demonstrate its cooperation by waiving its privilege and then compelling an employee "to submit to an interview by company counsel on pain of discharge if he refused." ${ }^{\circ 2}$ Forcing the corporation to turn over the compelled testimony of the employee only exacerbated the harm of the compelled waiver.

Wicker testified that "the overwhelming [] majorit[y] of respondents to the survey ${ }^{63}$ and the overwhelming experience of people that I've talked to tell us that they've experienced these kinds of compelled waivers in their cases, and they're becoming more and more common." ${ }^{64} \mathrm{He}$ further testified that "the effects of the erosion of the privilege work on the adversary system and are as serious as the effect on individuals. ${ }^{\circ 5}$ The encroachment upon the privilege harms not only the parties involved, but also the candor of the attorney-client relationship that was deemed important enough to justify the privilege in the first place. ${ }^{66}$

At the same Sentencing Commission hearing in March 2006, Susan Hackett, Senior Vice President and General Counsel for the Association of Corporate Counsel, testified on behalf of the Coalition to Preserve the Attorney-Client Privilege. ${ }^{67}$ She presented the results of a survey on privilege erosion issues, which was conducted by the Association of Corporate Counsel in $2005 .^{68}$ According to Ms. Hackett:

\footnotetext{
hearings/03_15_06/0315USSC.pdf [hereinafter March 2006 U.S.S.C. Transcript].

60. Id. at 101 .

61. $I d$.

62. Id. at 102 .

63. The survey referred to here was conducted by the Association of Corporate Counsel and is subsequently discussed by Susan Hackett in this note. See infra.

64. March 2006 U.S.S.C. Transcript, supra note 59, at 103-04.

65. Id. at 106 .

66. Id.

67. This Coalition consists of: the American Chemistry Council, the American Civil Liberties Union, the Association of Corporate Counsel, Business Civil Liberties, Inc., the Business Roundtable, the Financial Services Roundtable, Frontiers of Freedom, the National Association of Criminal Defense Lawyers, the National Association of Manufacturers, the National Defense Industrial Association, the Retail Industrial Leaders Association, the U.S. Chamber of Commerce, and the Washington Legal Foundation. Id. at 108 (statement of Susan Hackett, Senior Vice President and General Counsel for the Association of Corporate Counsel).
}

68. Id. at 111 . 
[C]ompanies faced with a potential investigation, prosecution or enforcement action, 1) are increasing in number to the point that waiver requests or expectations are considered routine; 2 ) have no meaningful ability to resist waiver expectations or demands however they are presented; 3 ) will face severe consequences if they do insist on exercising their privilege rights; and 4) suffered a significant and discernable chill in their lawyer/client relationships negatively impacting the lawyer's ability to work with clients to adopt, implement, monitor, and report on compliance initiatives that are poor to the company's legal health. ${ }^{69}$

Ms. Hackett also presented the results of a follow-up survey. Those responses painted a picture of "outrage" and "disbelief regarding government practices vis-à-vis the privilege." ${ }^{\prime 0}$ Respondents frequently used the terms "prosecutorial abuses" and "coercion." ${ }^{\text {" } 11}$ She highlighted some of the results of that survey: ${ }^{72}$

... Almost $75[\%]$ of both inside and outside counsel expressed agreement with $40[\%]$ agreeing strongly with a statement that, [ ]"A culture of waiver has evolved in which government agencies believe it is reasonable and appropriate for them to expect a company under investigation to broadly waive attorney/client privilege or work product protections,".... .

... Of the respondents who confirmed that they or their clients had been subject to an investigation in the last five years, approximately $30[\%]$ of in-house respondents and 51[\%] of outside counsel respondents said that the government expected a waiver as a condition to engaging in bargaining, or to be eligible to receive more favorable or lenient treatment.

Waiver is a condition of cooperation. Fifty-two percent of in-house respondents and $59[\%]$ of outside counsel respondents confirmed that they believed that there has been a marked increase in waiver requests as a condition of cooperation. And consistent with that finding, roughly half of all investigations for any other inquiry experienced by survey respondents resulted in a privilege waiver.

Further, and to refute the point often made that corporations are asked to waive but they volunteer to waive on their own, prosecutors typically request privilege waiver. It is rarely inferred by counsel. Of those who had been investigated, 55[\%] of outside counsel responded that waiver of the attorney/client privilege was requested by enforcement officials either directly or indirectly.

$\ldots$

The sentencing guidelines are listed by respondents as among the top three reasons given for waiver demands. This Commission specifically asked us to find out if it

69. March 2006 U.S.S.C. Transcript, supra note 59, at 111.

70. Id. at 113 .

71. Id.

72. Ex-Officio Commissioner Michael Elston of the Department of Justice points out that the survey only had about a $15[\%]$ response rate, and that the respondents may have "self-selected," but Ms. Hackett responds that "a $10[\%]$. . . response rate is considered statistically meaningful of a sampling of this size." Id. at 131. It is also significant that there were more than 1200 responses "from a wide range of practice environments and industry." Id. at 112. 
was reasonable to assume that the Sentencing Guidelines language was in some part responsible for privilege waivers problems, rather, if it was somewhat of a hook upon which waiver requests are hung, or if our concerns should be better addressed to others who engage in privilege waivers discussions on a direct basis.

But the facts are in. Outside counsel indicated that the DOJ's internal policies such as the Thompson, Holder, [and] McCallum Memorandum are cited most frequently when a reason for waiver is provided by a prosecutor or enforcement official. But the Sentencing Guidelines are cited second. In-house counsel placed the guidelines third behind the statement: A need for a quick and efficient resolution of the matter was proposed in the DOJ policies, respectively[.] $]^{73}$

That same day in March 2006, Mr. McCallum appeared before the Sentencing Commission to discuss removing privilege waiver as a consideration under the Sentencing Guidelines. ${ }^{74}$ At this hearing, Mr. McCallum testified that he knew of no "single complaint regarding prosecutorial misconduct and improperly demanding a waiver." 75 According to $\mathrm{Mr}$. McCallum, the government wanted waiver to continue to be considered as part of the Sentencing Guidelines on the grounds that not considering waiver "would be counterproductive to legitimate important law enforcement efforts." ${ }^{.76}$ Mr. McCallum's argument was based on the assumption that the government's need for information trumped the need for the privilege. He asserted that affecting a corporation's sentence based on its willingness to waive the privilege was key to "provok[ing] greater compliance, greater selfexamination and cooperation with law enforcement." $77 \mathrm{He}$ justified the government's approach based on the nature of a corporation and the sophistication of its attorneys. Mr. McCallum generalized that "corporations are represented by sophisticated corporate counsel, perfectly capable of evaluating the benefits of the disclosure to their client" and "not at all shy about complaining to the Department and to United States Attorneys about what they perceive to be overreaching tactics by Assistant United States Attorneys." ${ }^{78}$ Finally, he asserted that compelled waiver does not chill the

\footnotetext{
73. Id. at $115-17$.
}

74. In 2006, the Sentencing Guidelines were amended to eliminate the following language from the Culpability Score section: "[w]aiver of attorney-client privilege and of work product protections is not a prerequisite to a reduction in culpability score ... unless such waiver is necessary in order to provide timely and thorough disclosure of all pertinent information known to the organization." Sentencing Guidelines for United States Courts, 71 Fed. Reg. 28,063, 28,073 (May 15, 2006). The language was added in 2004, but eliminated in 2006 after the Commission determined "that the sentence at issue could be misinterpreted to encourage waivers." Id.

75. March 2006 U.S.S.C. Transcript, supra note 59, at 15.

76. Id. at 11 .

77. $I d$.

78. Id. at $14-15$. 
attorney-client relationship, that it does not reduce internal investigation, that its effect on employees is irrelevant, and that any collateral civil harm will dissipate if Federal Rule of Evidence 502(c) is adopted. ${ }^{79}$

\section{The McNulty Memo: Softening the Government's Approach}

In December 2006, the Department of Justice released an update to the Thompson Memo in response to public criticism and demands by Senator Arlen Specter. ${ }^{80}$ This memo, issued by Deputy Attorney General Paul J. McNulty, replaced the Thompson Memo and the McCallum Memo. ${ }^{81}$ Mr. McNulty acknowledged the prevailing concern that the practices of the Department were "discouraging full and candid communications between corporate employees and legal counsel." ${ }^{\circ 2} \mathrm{He}$ cautioned against requesting waivers without good reason and established a new policy requiring "written authorization" for any such request. ${ }^{83}$ Despite acknowledging the importance of the attorney-client privilege and work-product protection, however, the memo still approves of waiver requests "when there is a legitimate need for the privileged information." 84 This need can exist whenever the likely benefit of obtaining the information outweighs factors such as the ease of obtaining the information without the waiver, the "completeness of the voluntary disclosure already provided," and "the collateral consequences to a corporation of a waiver." 85

The McNulty Memo attempts to reduce the harshness of compelled waiver by distinguishing between requests for "purely factual information ... relating to the underlying misconduct ('Category I')," and requests for "attorney-client communications or non-factual attorney work product

79. Id. at $16-18$.

80. This memo was largely a response to Senator Specter's original introduction of the AttorneyClient Privilege Protection Act in 2006. In introducing this bill, Specter was trying to encourage McNulty to revise the Thompson Memo on his own. Sarah Johnson, Down to the Wire: Thompson Memo Revised?, CFO.COM, Dec. 8, 2006, http://www.cfo.com/printable/article.cfm/8401796/c_2984347?f=options. The criticism regarded two Department of Justice policies reflected in the Thompson Memo. First, the Department was sharply criticized for its method of compelling waiver of attorney-client privilege and work-product protection, as discussed in this note. $I d$. Second, the Department was under heavy scrutiny for a separate factor of "cooperation" which considered whether or not a corporation paid legal expenses for employees involved in the litigation. Id. This second concern is not discussed in this note.

81. McNulty Memo, supra note 7, at 1-2.

82. Id. at 1 .

83. Id. at 9 .

84. Id. at 8 .

85. Id. at 9 . 
('Category II')." ${ }^{\prime 86}$ Category I information may or may not actually be privileged or protected ${ }^{87}$ Category II information is clearly protected by the attorney-client privilege or work-product protection. It includes direct communications between a corporation and its attorney "before, during, and after the underlying misconduct occurred," as well as any attorney workproduct "containing counsel's mental impressions and conclusions, legal determinations reached as a result of internal investigation, or legal advice

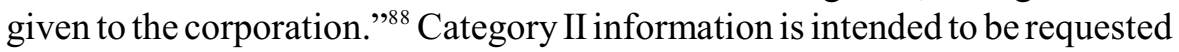
only "in rare circumstances." ${ }^{89}$ If a corporation does not waive its privilege as to Category II information, the prosecutor is instructed not to consider this in making a charging decision, but in an arguably semantic twist, "[p]rosecutors may always favorably consider a corporation's acquiescence to the government's waiver request in determining whether a corporation has cooperated in the government's investigation." 90

The response to the McNulty Memo was unfavorable. Few commentators seemed to feel that it was enough. American Bar Association President Karen J. Mathis claimed that the changes fell "far short" of protecting attorney-client privilege and work-product protection. " "Instead of eliminating the improper Department practice of requiring companies to waive their privileges in return for cooperation credit ... the new policy . . . merely requires high level Department approval before waiver requests can be made." ${ }^{.92}$ In a statement to the House Judiciary Committee, the Coalition to Preserve the Attorney-Client Privilege said, "[s]o long as the possibility of waiver demands exists, the Justice Department's policy will continue to hamper and chill corporate compliance programs and investigations. ${ }^{, 93}$

In March 2007, Richard White, 2007 Chairman of the Board of the Association of Corporate Counsel, testified before the House Judiciary Committee that "the McNulty Memorandum offers only some surface, procedural changes and does nothing to address our larger concerns or abusive

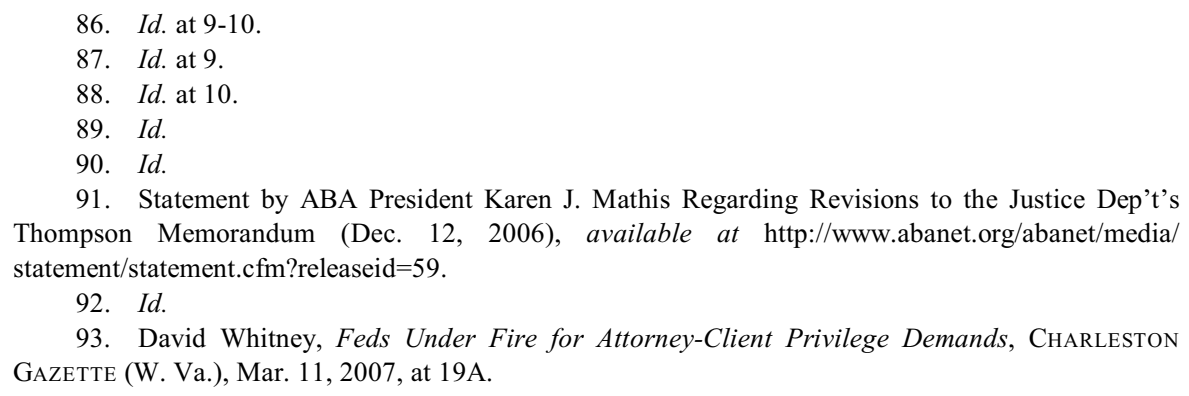

91. Statement by ABA President Karen J. Mathis Regarding Revisions to the Justice Dep't's Thompson Memorandum (Dec. 12, 2006), available at http://www.abanet.org/abanet/media/ statement/statement.cfm?releaseid $=59$.

92. Id.

93. David Whitney, Feds Under Fire for Attorney-Client Privilege Demands, Charleston Gazette (W. Va.), Mar. 11, 2007, at 19A. 
prosecutorial practices." $94 \mathrm{He}$ told the committee that his "corporate colleagues know from experience that many federal enforcement officials rely almost exclusively on informal demands to coerce corporations to waive their attorney client and work product protections," and that "[n]o formal demand is necessary given the culture of waiver the DOJ and other agencies have fostered in the past few years." 95 Finally, he pointed out that "establishing a clearer policy" for requesting waiver assumes that prosecutors "have a right to determine when a corporate client's privilege rights deserve protection and when they don't." ${ }^{\prime 96}$ But "the privilege is that of the client alone" ${ }^{97}$ and does not belong to "the prosecutor who believes it might be convenient if it were waived." ${ }^{\circ 8}$ In a public statement by the Association of Corporate Counsel, the ACC said that " $[\mathrm{t}]$ he McNulty Memo does more to protect unabated waiver demands made by prosecutors, but still misses the fundamental point: that prosecutors don't get to decide when they think waiver is necessary." 99

This authorization requirement is little comfort to those who believe that the government should never request a waiver. Stanton Anderson, Senior Counsel to the President of the United States Chamber of Commerce, issued a statement saying, "As long as the [Deputy Attorney General's Office] can decide whether or not to demand waiver, the privilege is uncertain. An uncertain privilege is no privilege at all." ${ }^{100}$ Sutherland Asbill \& Brennan pointed out that it does not solve the selective waiver issue and it "leaves enormous room for interpretation by the Department of Justice." ${ }^{101}$ Frederick J. Krebs, president of the Association of Corporate Counsel, opined that "this

94. The McNulty Memorandum's Effect of the Right to Counsel in Corporate Investigations: Hearing Before the Subcomm. on Crime, Terrorism, and Homeland Security of the H. Comm. on the Judiciary, 110th Cong. 78 (2007) (prepared statement of Richard T. White, Chairman of the Board of Directors, Association of Corporate Counsel) [hereinafter White Statement].

95. Id. at $78-79$

96. Id. at 79 .

97. Hunt v. Blackburn, 128 U.S. 464, 470 (1888).

98. White Statement, supra note 94, at 79 .

99. Memorandum from the Association of Corporate Counsel, What Does the DOJ's Issuance of the "McNulty Memorandum" Mean for You and Your Client (Dec. 13, 2006), available at http:www.acc.com/public/attyclientpriv/mcnulty-tp.pdf.

100. Press Release, U.S. Chamber of Commerce, New DOJ Policy Does Not Adequately Protect Attorney-Client Privilege (Dec. 12, 2006), available at http://www.acc.com/public/attyclientpriv/ mcnultymemochamberpressrelease.pdf.

101. Sutherland Asbill \& Brennan LLP, Legal Alert: Department of Justice Modifies Thompson Memorandum Guidance on Attorney-Client Privilege Waivers and Advancement of Attorneys' Fees in Government Investigations (Jan. 19, 2007), available at http://www.sablaw.com/files/tbl_s10News\%5 CFileUpload44\%5C16442\%5CLegalAlertLitigationDepartmentofJusticeModifiesThompsonMemorand umGuidance11907.pdf. 
memo is a day late and a dollar short."102 He claimed that the changes "will not put an end to the 'culture of waiver' that exists within the DOJ." ${ }^{103}$ Senator Patrick Leahy expressed his concern that "depending on how the new policies are implemented, prosecutors may still be able to inappropriately consider a corporation's waiver of this important privilege." ${ }^{104}$ Stephanie Martz, director of the White Collar Crime Project at the National Association of Criminal Defense Lawyers, strongly disagreed with the McNulty Memo's decision to give corporations credit for waiving their privileges. ${ }^{105}$ She claimed that "we're at the point where waiver requests are routine, and the only way we can try to put that genie back in the bottle is by not allowing corporations to get credit for granting it." 106

\section{Selective Waiver}

\section{A. Introduction of the Doctrine of Selective Waiver}

One very significant problem with compelled waiver is that it eliminates the privilege entirely for all information disclosed, thus exposing the corporation's confidential information to any potential adversary. Confidentiality is a key element of the attorney-client privilege, and once the confidentiality of the information is compromised, the attorney-client privilege no longer applies. ${ }^{107}$ The work-product protection is likewise waived by disclosure of otherwise protected documents. ${ }^{108}$ Therefore, once the corporation discloses the information to the government, it is no longer able to claim either the attorney-client privilege or the work-product protection for that information. Upon disclosure to the government, the information becomes discoverable by any party, including civil litigants.

In 1977, the Eighth Circuit Court of Appeals attempted to ameliorate these harsh effects of cooperating with the government by introducing the

102. Press Release, Assoc'n of Corporate Counsel, DOJ's “McNulty Memorandum" Falls Short on Prosecutorial Reforms, Says Assoc'n of Corporate Counsel (Dec. 12, 2006), available at https://secure.acca.com/php/cms/index.php?id=34\&action=item\&item_id=20061212_1402.

103. $I d$.

104. Reaction of Sen. Patrick Leahy (D-Vt.), Ranking Member and Incoming Chairman, Senate Judiciary Comm., To Revisions to the Thompson Memorandum (Dec. 12, 2006), available at http://www.acc.com/public/attyclientpriv/mcnultymemosenleahystatement.pdf.

105. Lynnley Browning, U.S. Moves to Restrain Prosecutors, N.Y. Times, Dec. 13, 2006, at C1.

106. Id.

107. See In re Qwest Commc'ns Int'1 Inc., 450 F.3d 1179, 1185 (10th Cir. 2006).

108. See id. at 1186 . 
concept of "limited waiver" in Diversified Industries, Inc. v. Meredith ${ }^{109}$ This concept has since come to be known as the doctrine of selective waiver. ${ }^{110}$ In Diversified, the Securities and Exchange Commission (SEC) was investigating Diversified Industries based on reports that it may have bribed its customers' purchasing agents and been involved in other illegal activities. ${ }^{111}$ After the SEC initiated its investigation, Diversified's board of directors hired a law firm to conduct an internal investigation and assess the suspicious activity. ${ }^{112}$ At that point, there was no pending litigation and the law firm was not hired to represent Diversified in any future litigation. ${ }^{113}$ The law firm produced a memorandum in June 1975 that outlined "historical matters" and the proposed investigation. ${ }^{114}$ One month later, one of Diversified's customers, Weatherhead, brought a civil suit against Diversified alleging that Diversified bribed Weatherhead employees to purchase significant amounts of inferior copper from Diversified. ${ }^{115}$ During discovery, Weatherhead requested copies of the law firm's report, minutes of the meeting where the findings were discussed, and a copy of the letter that Diversified's president had issued to various officers and managers of the corporation sharing the results of the investigation. ${ }^{116}$

The Diversified court held that the law firm's report, the relevant corporate minutes, and the letter from Diversified's president were all entitled to protection; the issue was "whether Diversified waived its attorney-client privilege with respect to the privileged material by voluntarily surrendering it to the SEC pursuant to an agency subpoena." 117 In a remarkably sparse portion of the opinion, the court held that "only a limited waiver of the privilege occurred." 118 The rationale for this holding was that "[t]o hold otherwise may have the effect of thwarting the developing procedure of corporations to employ independent outside counsel to investigate and advise

109. 572 F.2d 596, 611 (8th Cir. 1978).

110. See, e.g., Nancy Horton Burke, The Price of Cooperating with the Government: Possible Waiver of Attorney-Client and Work Product Privileges, 49 BAYLOR L. Rev. 33, 34 (1997).

111. Diversified, 572 F.2d at 600.

112. Id.

113. Id.

114. Id.

115. Id.

116. Id. at 599-601.

117. Id. at 611 .

118. Id. 
them in order to protect stockholders, potential stockholders, and customers." 119

\section{B. The Systematic Rejection of Selective Waiver}

Diversified appeared to create a doctrine that would protect corporations who cooperated with the government. ${ }^{120}$ Under Diversified, a corporation could waive its attorney-client privilege or work-product protections vis-à-vis the government in order to cooperate with a government investigation, while still being able to invoke those protections against other parties in future civil cases. This doctrine encouraged corporations to cooperate with government investigations. In the wake of Diversified, however, the doctrine of selective waiver was systematically rejected by every other circuit considering the issue. $^{121}$

In 1981, the D.C. Circuit rejected selective waiver in Permian Corp. $v$. United States. ${ }^{122}$ The Permian court rejected the doctrine for three reasons. First, the court found no connection between the concept of limited waiver and the confidentiality of the attorney-client relationship. ${ }^{123}$ Although the court could see a benefit in encouraging voluntary cooperation with government investigations, it did not see how encouraging cooperation with the government would improve the attorney-client relationship. ${ }^{124}$ With or without selective waiver, a client is free to maintain his right to attorney-client confidentiality "by consistently asserting the privilege, even when the discovery request comes from a 'friendly' agency." 125 Therefore, selective waiver was not justified by the purposes underlying the attorney-client privilege.

Second, the court believed that it was unfair to allow a defendant to "pick and choose among his opponents, waiving the privilege for some and resurrecting the claim of confidentiality to obstruct others . . ." ${ }^{126}$ If the corporation is willing to waive its privilege in order to obtain a benefit, it cannot later resurrect that privilege as a weapon to prevent other litigants from

119. Id.

120. Id. at 596.

121. Id. This note looks only at the federal courts' treatment of selective waiver, and does not consider the treatment of the issue by any state court.

122. 665 F.2d 1214 (D.C. Cir. 1981).

123. Id. at $1220-21$.

124. Id. at 1221 .

125. Id.

126. $I d$. 
obtaining the information. ${ }^{127}$ The privilege is to be narrowly construed because it "inhibits the truth-finding process," and so the courts should not allow it to be used as "a tool for selective disclosure." 128 The court held that "the attorney-client privilege should be available only at the traditional price: a litigant who wishes to assert confidentiality must maintain genuine confidentiality." 129

Third, the court was unable to find a persuasive public policy reason to recognize the doctrine because it could be both a benefit and a detriment to government agencies. ${ }^{130}$ "It is apparent that such a doctrine would enable litigants to pick and choose among regulatory agencies in disclosing and withholding communications of tarnished confidentiality for their own purposes." ${ }^{131}$ Therefore, any public policy reason to encourage disclosure to one government agency would be obliterated by the doctrine's negative effect on other agencies.

The Fourth Circuit followed the D.C. Circuit in 1988 by rejecting selective waiver in In re Martin Marietta Corp. ${ }^{132}$ In a very matter-of-fact opinion, the Martin Marietta court held that, with a possible exception for opinion work-product, once a corporation has revealed the documents to the government, it has waived its privilege because it no longer has the required expectation of confidentiality. ${ }^{133}$

Three years later, the Third Circuit rejected selective waiver in Westinghouse Electric Corp. v. Republic of the Philippines. ${ }^{134}$ The Westinghouse court gave several reasons for its rejection of the doctrine. One, it emphasized the well-settled belief that a privilege should be narrowly construed because it "obstructs the truth-finding process." ${ }^{135}$ Two, it could find no reason to recognize such protection where a party was willing to waive the protection vis-à-vis a third party. ${ }^{136}$ The court reasoned that if a party was willing to divulge the protected information to a third party, it was unlikely that the party would keep that information from its attorney. ${ }^{137}$ Three, the 
court found Diversified's rationale - that without selective waiver corporations would hesitate to seek legal advice-to be less than compelling. ${ }^{138}$ Like the Permian court, the Third Circuit held that selective waiver did nothing to encourage a corporation to seek "informed legal assistance" and thus was not justified by the principles underlying the privilege. ${ }^{139}$ Instead, "it merely encourages voluntary disclosure to government agencies, thereby extending the privilege beyond its intended purpose."140 Finally, the court could not find any reason to create a new privilege. While there was certainly reason to encourage "voluntary cooperation with government investigations," there was "little reason to believe . . . that this interest outweighs "the fundamental principle that "the public . . . has a right to every man's evidence." "'141 Furthermore, the court was not convinced that selective waiver was necessary to encourage corporations to cooperate with government investigations, particularly where the party at issue, Westinghouse, had itself disclosed the privileged materials to the SEC without the protection of a selective waiver rule. ${ }^{142}$

In 1993, the Second Circuit refused to adopt the selective waiver doctrine in In re Steinhardt Partners, L.P. ${ }^{143}$ The Steinhardt court was also persuaded by Permian's reasoning that selective waiver allowed a litigant to unfairly pick and choose among its opponents. The court held that "selective assertion of privilege should not be merely another brush on an attorney's palette, utilized and manipulated to gain tactical or strategic advantage." ${ }^{\prime 44}$ Neither is it fair to allow a party " to invoke the privilege as to communications whose confidentiality he has already compromised for his own benefit." ${ }^{145}$ It also adopted the Permian court's reasoning that selective waiver has no effect on the underlying purpose of the attorney-client privilege, which is to foster "frank communication between attorney and client." ${ }^{146}$ Finally, the Steinhardt court found no reason to recognize a selective waiver protection because the government had continued to receive voluntary cooperation from corporations in spite of the consistent rejection of the selective waiver doctrine in the

138. Id. at $1424-25$.

139. Id. at 1425 .

140. Id.

141. Id. at 1425-26 (quoting Univ. of Pa. v. E.E.O.C., 493 U.S. 182, 189 (1990) (citations omitted)).

142. Id. at 1426 .

143. In re Steinhardt Partners, L.P., 9 F.3d 230, 235 (2d Cir. 1993).

144. Id.

145. Id. (quoting Permian Corp. v. United States, 665 F.2d 1214, 1221 (D.C. Cir. 1981)).

146. $I d$. 
sixteen years since Diversified. ${ }^{147}$ A corporation had other reasons to cooperate with the government, such as the avoidance of "formal investigation and enforcement litigation," the hope of possible leniency, and the obtainment of "an opportunity to narrow the issues in any resulting litigation," that made selective waiver unnecessary. ${ }^{148}$

The Federal Circuit rejected selective waiver in 1997 in Genentech, Inc. v. United States International Trade Commission. ${ }^{149}$ The court held that "Genentech has presented no compelling arguments as to why we should apply such a limited waiver theory in this case." ${ }^{\prime 50}$ The case was distinguished from similar cases in other circuits because the disclosure at issue was inadvertent and "the result of inadequate screening procedures." 151 As such, there was no reason to recognize a selective waiver where the disclosures were not compelled. ${ }^{152}$

In 1997, the First Circuit rejected the doctrine in United States v. Massachusetts Institute of Technology. ${ }^{153}$ Consistent with previous courts that had rejected selective waiver, the Massachusetts Institute of Technology court rationalized that the privilege "hinders the courts in the search for truth," and thus should be narrowly defined, and unfairly allows a party "to disclose materials to one outsider while withholding them from another." ${ }^{\text {" }} 154$ The court was not convinced by the government's interest in encouraging voluntary disclosure because the government had other means to secure the necessary information and had the ability to seek legislation from Congress if it needed more assistance. ${ }^{155}$ The court was equally unconvinced that refusing to adopt selective waiver would prevent corporations from obtaining adequate legal advice. ${ }^{156}$ Furthermore, the Massachusetts Institute of Technology court believed that the lack of selective waiver "makes the law more predictable and certainly eases its administration," where "[f]ollowing the Eighth Circuit's approach would require, at the very least, a new set of difficult line-drawing

147. Id. at 236 (citing Brief for Sec. \& Exch. Comm'n as Amici Curiae Supporting Respondent at 3, 20-25; Steinhardt, 9 F.3d 230 (2d Cir. 1993) (No. 873)).

148. $I d$.

149. 122 F.3d 1409, 1417 (Fed. Cir. 1997).

150. Id.

151. $I d$.

152. $I d$.

153. United States v. Mass. Inst. of Tech. (MIT), 129 F.3d 681, 684-85 (1st Cir. 1997).

154. $I d$.

155. Id. at 685 .

156. Id. 
exercises that would consume time and increase uncertainty." 157 The court was unwilling to make exceptions for disclosures to the government, particularly those made purposefully in order to obtain a benefit or to avoid a disadvantage, because it feared it would be going down a path "which has no logical terminus." 158

The Sixth Circuit became the seventh circuit court to reject selective waiver in 2002 with In re Columbia/HCA Healthcare Corp. Billing Practices Litigation. ${ }^{159}$ Following the majority viewpoint, the Sixth Circuit rejected the doctrine for the same reasons as the other circuit courts. More specifically, the court held that the doctrine of selective waiver was unrelated to the underlying purposes of the attorney-client privilege, ${ }^{160}$ that the doctrine unfairly allowed a party to pick and choose among its opponents, "waiving the privilege for some and resurrecting the claim of confidentiality as to others," recognition of selective waiver would have " no logical terminus." "162 The court was also reluctant to give the government a tool that inhibited the truth finding process when the government had the means to secure the necessary information in other ways. ${ }^{163}$ Finally, the court held that when a corporation makes the tactical decision to waive its attorney-client privilege in exchange for more favorable treatment by the government, it should not be free from the price of that decision. ${ }^{164}$ As to work-product protection waiver, the court held that the same reasons applied as in the attorney-client privilege analysis: " $t \mathrm{t}] \mathrm{he}$ ability to prepare one's case in confidence, which is the chief reason articulated in Hickman, supra, for the work product protections, has little to do with talking to the Government." 165 In other words, encouraging cooperation with the government was completely unrelated to the purposes of the work-product protection doctrine, and the court had no interest in endorsing such a significant expansion of the doctrine.

Most recently, in 2006, the Tenth Circuit rejected the selective waiver doctrine in In re Qwest Communications International Inc., Securities

157. Id.

158. $I d$. at 686 .

159. 293 F.3d 289, 302 (6th Cir. 2002).

160. Id. at 303 .

161. Id. (quoting Permian Corp. v. United States, 665 F.2d 1214, 1221 (D.C. Cir. 1981) (alteration in original)).

162. Id. (quoting MIT, 129 F.3d at 686).

163. Id. (quoting MIT, 129 F.3d at 685).

164. Id. at 304.

165. Id. at 306. 
Litigation. ${ }^{166}$ The Qwest court held that selective waiver was not needed "to assure cooperation with law enforcement, to further the purposes of the attorney-client privilege or work-product doctrine, or to avoid unfairness to the disclosing party." ${ }^{167}$ Like the Westinghouse court, the court held that Qwest's cooperation in spite of the non-existence of the selective waiver doctrine showed that the doctrine was not necessary to encourage cooperation. ${ }^{168}$ The court was also persuaded by the fact that the Department of Justice did not support Qwest's assertion that the doctrine would benefit the government. ${ }^{169}$ As to promoting the purposes of the attorney-client privilege and work-product doctrine, namely encouraging attorney-client communication, the court suggested that "selective waiver could have the opposite effect of inhibiting such communication." ${ }^{170}$ Since these protections would be easier to waive, the client would be less likely to depend on the attorney-client privilege and the attorney would be less likely to depend on the work-product protection. ${ }^{171}$ Finally, the court was unconvinced that Qwest would suffer any unfairness from the rejection of the doctrine where "Qwest disclosed the [documents] in the face of the known threat from Plaintiffs, the absence of Tenth Circuit precedent, and a dearth of favorable circuit authority." ${ }^{172}$ Instead, Qwest determined that the disclosures were beneficial in spite of the risk of waiver. ${ }^{173}$

In May 2006, the Advisory Committee on Evidence Rules proposed a new Federal Rule of Evidence that would codify selective waiver, ${ }^{174}$ but this too has been rejected. The original proposal for Federal Rule of Evidence 502 included a provision that would have allowed selective waiver for disclosures of privileged or protected information "when made to a federal public office or agency in the exercise of its regulatory, investigative, or enforcement authority." 175 When this proposed rule was finalized and introduced to

166. 450 F.3d 1179, 1192 (10th Cir. 2006).

167. Id.

168. Id. at 1193 .

169. $I d$.

170. Id. at 1195 .

171. Id.

172. Id. at 1196 .

173. Id.

174. Report of the Advisory Comm. on Evidence Rules, Proposed Amendment to the Fed. Rule of Evidence: Rule 502. Attorney-Client Privilege and Work Product; Limitations on Waiver (May 15, 2006), available at $\mathrm{http}: / / \mathrm{www}$.uscourts.gov/rules/Reports/EV05-2006.pdf [hereinafter May 2006 A.C. Report]. 175. Id. 
Congress in December 2007, however, the provision for selective waiver was notably absent. ${ }^{176}$

\section{The Selective Waiver Doctrine: Unlikely to Be Revived}

Given the reasons discussed by the First, Second, Third, Fourth, Sixth, Tenth, D.C., and Federal Circuits, which seem to find selective waiver as illogical and unnecessary, it comes as no surprise that selective waiver was omitted from the final proposal for Rule 502. First, there is no correlation between selective waiver and the purposes of the attorney-client privilege or the work-product protection. ${ }^{177}$ It does nothing to improve the attorney-client relationship. If anything, it makes the protections easier to waive, thus failing to enhance their purposes. ${ }^{178}$ Second, it is unfair to allow a corporation to pick and choose its opponents. ${ }^{179}$ Selective waiver would be "just another brush on the attorney's palette," which could be used as a weapon against adversaries. ${ }^{180}$ Third, there is no inherent unfairness in refusing to recognize selective waiver for a corporation who determined that the benefit of disclosure outweighed the downside of waiving its protections. ${ }^{181}$ If a party makes a tactical decision to waive the privilege in order to obtain some benefit, it is not unfair to also make that party bear the cost of that decision. ${ }^{182}$ Fourth, privileges should be narrowly construed because they inhibit factfinding. ${ }^{183}$ In order to recognize a privilege, there must be a reason sufficient to overcome the impairment on the fact-finder. ${ }^{184}$ Encouraging cooperation with law enforcement is not a sufficient reason because the government has other ways to get the information it needs, ${ }^{185}$ a party has other reasons to

176. See S. 2450, 110th Cong. (2007), available at http://www.govtrack.us/congress/billtext .xpd?bill=s110-2450.

177. See In re Columbia/HCA Healthcare Corp., 293 F.3d 289, 302 (6th Cir. 2002); United States v. MIT, 129 F.3d 681, 685 (1 st Cir. 1997); In re Steinhardt Partners, L.P., 9 F.3d 230, 235 (2d Cir. 1993); Westinghouse Elec. Corp. v. Republic of the Phil., 951 F.2d 1414, 1425 (3d Cir. 1991); Permian Corp. v. United States, 665 F.2d 1214, 1220-21 (D.C. Cir. 1981).

178. See In re Qwest Commc'ns Int'l Inc., 450 F.3d 1179, 1195 (10th Cir. 2006).

179. See In re Columbia, 293 F.3d at 303; MIT, 129 F.3d at 685; In re Steinhardt, 9 F.3d at 235; Westinghouse, 951 F.2d at 1425; Permian, 665 F.2d at 1221.

180. In re Steinhardt, 9 F.3d at 235.

181. See In re Qwest, 450 F.3d at 1196; In re Columbia, 293 F.3d at 304 n.23; MIT, 129 F.3d at 686.

182. In re Columbia, 293 F.3d at 304.

183. See In re Qwest, 450 F.3d at 1195; In re Columbia, 293 F.3d at 294; MIT, 129 F.3d at 685; Westinghouse, 951 F.2d at 1423; Permian, 665 F.2d at 1221.

184. Westinghouse, 951 F.2d at 1425.

185. MIT, 129 F.3d at 685 . 
cooperate, ${ }^{186}$ and the facts of the cases show that obtaining cooperation is not a problem, even without recognition of selective waiver. ${ }^{187}$ Finally, if selective waiver is recognized, there seems to be "no logical terminus." ${ }^{188}$ This results in "difficult line drawing" and "uncertainty" in the law. ${ }^{189}$

Furthermore, selective waiver does nothing to ameliorate the hardship a corporation suffers when it is compelled to waive its privilege with respect to the government itself. In fact, the purpose of the Rule is to make corporations more likely to waive their privileges and protections vis-à-vis the government. It is clear from the Committee Note to Rule 502 that the purpose of selective waiver is to increase corporate cooperation in government investigations, meaning it would make it easier for corporations to waive their attorney-client privileges and work-product protections when they are being investigated by the government. ${ }^{190}$

Routinely compelled waivers of attorney-client privilege and workproduct protection mean that corporations have no protection at all against the government. Regardless of the protection given a corporation vis-à-vis civil opponents, the removal of the privilege as to the government is still highly detrimental to the purposes underlying the attorney-client privilege and workproduct protection doctrine. If a corporate client knows that its communications are likely to be left unprotected, it will be less likely to be candid with its attorney. Encouraging "full and frank communication between attorneys and their clients" is the very purpose of the attorney-client privilege.$^{191}$ And if an attorney knows that his or her mental impressions and other writings are not going to be protected, that attorney is going to be more hesitant to put things in writing. This will lead to inefficiency and reduced service to the client, and the legal profession will be demoralized, just as the United States Supreme Court warned in Hickman. ${ }^{192}$

186. In re Steinhardt, 9 F.3d at 236.

187. See In re Qwest, 450 F.3d at 1193; In re Steinhardt, 9 F.3d at 236; Westinghouse, 951 F.2d at 1426.

188. See In re Columbia, 293 F.3d at 303; MIT, 129 F.3d at 686.

189. MIT, 129 F.3d at 685.

190. See May 2006 A.C. Report, supra note 174, at 14 (stating that the rule "furthers the important policy of cooperation with government agencies, and maximizes the effectiveness and efficiency of government investigations").

191. Upjohn Co. v. United States, 449 U.S. 383, 389 (1981).

192. Hickman v. Taylor, 329 U.S. 495, 511 (1947). 


\title{
IV. The Solution: The Attorney-Client Privilege Protection Act
}

\author{
A. Introduction of the Attorney-Client Privilege Protection Act and Public \\ Response to the Act
}

A more comprehensive solution to the erosion of the attorney-client privilege and the work-product protection was presented in January 2007 when Senator Arlen Specter proposed the "Attorney-Client Privilege Protection Act." 193 The purpose of this bill is to create a new statute, 18 U.S.C. $\S 3014$, which will protect these important doctrines from infringement by federal prosecutors. ${ }^{194}$ The proposed statute provides, in relevant part:

(a) Definitions - In this section:

(1) ATTORNEY-CLIENT PRIVILEGE-The term "attorney-client privilege" means the attorney-client privilege as governed by the principles of the common law, as they may be interpreted by the courts of the United States in the light of reason and experience, and the principles of article $\mathrm{V}$ of the Federal Rules of Evidence.

(2) ATTORNEY WORK PRODUCT - The term "attorney work product" means materials prepared by or at the direction of an attorney in anticipation of litigation, particularly any such materials that contain a mental impression, conclusion, opinion, or legal theory of that attorney.

(b) In General - In any Federal investigation or criminal or civil enforcement matter, an agent or attorney of the United States shall not-

(1) demand, request, or condition treatment on the disclosure by an organization, or person affiliated with that organization, of any communication protected by the attorney-client privilege or any attorney work product;

(2) condition a civil or criminal charging decision relating to a organization, or person affiliated with that organization, on, or use as a factor in determining whether an organization, or person affiliated with that organization, is cooperating with the Government-

(A) any valid assertion of the attorney-client privilege or privilege for attorney work product;

....

(3) demand or request that an organization, or person affiliated with that organization, not take any action described in paragraph (2).

(c) Inapplicability-Nothing in this Act shall prohibit an agent or attorney of the United States from requesting or seeking any communication or material that such agent or attorney reasonably believes is not entitled to protection under the attorneyclient privilege or attorney work product doctrine.

(d) Voluntary Disclosures - Nothing in this Act is intended to prohibit an organization from making, or an agent or attorney of the United States from

193. Shiv Kumar, Senator Specter Introduces Attorney-Client Privilege Protection Act, U.S. Fed NEws, Jan. 23, 2007. The Act was originally introduced in December 2006, but after the McNulty Memo failed to address the concerns that motivated the ACPPA, Senator Specter reintroduced the Act in January, 2007. Sutherland Asbill \& Brennan LLP, supra note 101.

194. Attorney-Client Privilege Protection Act of 2007, S. 186, 110th Cong. § 3 (2007). 
accepting, a voluntary and unsolicited offer to share the internal investigation materials of such organization. ${ }^{195}$

This statute forbids the type of compelled waivers the government currently pursues. In fact, this statute removes all of the government's leverage for getting corporations to waive their attorney-client privilege or work-product protections. No longer will any federal prosecutor be allowed to ask a corporation to waive its privilege or protection in exchange for cooperation credit in any form. The corporation cannot be given positive credit for a waiver, nor can it be given negative credit for refusing to waive its privileges or protections.

As soon as it was proposed, Senator Specter's Attorney-Client Privilege Protection Act was embraced with relief by the legal community. American Bar Association President Karen J. Mathis called the Act "critically important to our nation's economic and legal health." ${ }^{196}$ She urged support for the Act on the grounds that it "strikes the proper balance between the legitimate needs of prosecutors and regulators and the constitutional and fundamental legal rights of individuals and organizations." ${ }^{197}$ The Coalition to Preserve the Attorney-Client Privilege released a statement in December 2007 "to thank Chairman Specter for sponsoring legislation that would restore the balance that once existed between the legitimate needs of Justice Department prosecutors and the legal protections and rights guaranteed under the American system of justice to employees of companies and other organizations under investigation." 198 Andrew Weissmann, former director of the Enron Task Force and partner at Jenner \& Block LLP in New York, and Ana R. Bugan, an associate at Jenner \& Block in Chicago, praised Specter, saying he "has fortunately not been deterred by the [McNulty Memo]" and its "insufficient" policy changes. ${ }^{199}$ Caroline Fredrickson, director of the ACLU Washington Legislative Office, called the Act "a common sense approach to restoring one of the fundamental legal protections guaranteed under the

195. $I d$.

196. Statement by ABA President Karen J. Mathis regarding the Attorney-Client Privilege Protection Act of 2006 (Dec. 7, 2006), available at http://www.abanet.org/abanet/media/statement/statement .cfm?releaseid $=52$.

197. $I d$.

198. Statement by the Coal. to Preserve the Attorney-Client Privilege on Sen. Arlen Specter's Introduction of the "Attorney-Client Privilege Protection Act of 2006" (Dec. 7, 2006), available at http://www.abanet.org/poladv/priorities/privilegewaiver/2006dec07_privwaiv_coalitionpr.pdf. 2007.

199. Andrew Weissmann \& Ana R. Bugan, Thompson Gunners, Daily Deal/The Deal, Jan. 29, 
Constitution to those under investigation., ${ }^{200}$ Edwin Meese III, former United States Attorney General and chairman of the Center for Legal and Judicial Studies at the Heritage Foundation, said that "Senator Specter is to be commended for his efforts to ensure that the constitutional protections for the right to counsel are preserved in the investigation or prosecution of business organizations." 201

B. The ACPPA Would Restore an "Absolute" Attorney-Client Privilege Which Is Necessary in Order to Restore the Ability of Corporations to Seek Effective Legal Advice From Their Attorneys

According to Dean Wigmore, a privilege must be absolute in order to be effective. ${ }^{202}$ "The Supreme Court has not only generally adopted Dean Wigmore's approach to privilege analysis .... [It] has specifically endorsed Wigmore's insistence on absolute privileges." ${ }^{203}$ Although the U.S. Attorney's Office has suggested that the privilege may be ignored when the government needs the information or when it affects the Department of Justice's ability "to prosecute in a timely and efficient manner," ${ }^{204}$ this assertion is directly contrary to the well-established assumptions of privilege law. Privileges are specifically recognized in spite of their limitations on the fact-finding process.

One prominent scholar, Professor Edward Imwinkelried, suggests that the privilege does not have to be absolute in order to be effective. ${ }^{205}$ However, even if this is so, routinely compelled waiver is an effective abrogation of the privilege. Even if one does not subscribe to Wigmore's theory that the privilege must be absolute, one cannot look at the current culture of waiver and think that any privilege survives. Where corporations know that their protections and privileges must be waived in order to get credit for cooperation and to avoid indictment, the attorney-client privilege and workproduct protections are essentially non-existent. Where the attorney-client

200. Press Release, ACLU, American Civil Liberties Union Welcomes Attorney-Client Privilege Protection Act, Says Bill Would Safeguard Constitutional Right to Counsel, US Fed News, Dec. 7, 2006.

201. Press Release, Heritage Found., Meese Praises Approach of Attorney-Client Privilege Protection Act (Dec. 7, 2006), available at http://www.heritage.org/Press/NewsReleases/nr120706a.cfm.

202. Edward J. Imwinkelried, Questioning the Behavioral Assumption Underlying Wigmorean Absolutism in the Law of Evidentiary Privileges, 65 U. PitT. L. Rev. 145, 147 (2004).

203. Id. at 148 .

204. March 2006 McCallum Statement, supra note 44.

205. Imwinkelried, supra note 202, at 180 (concluding that "[t]he available empirical data undercuts the assumption that the average layperson is as obsessed by a fear of subsequent judicially compelled disclosure as Wigmore supposed.”). 
privilege and work-product protection are not effective, their underlying purposes are nullified. Attorney-client relationships are harmed and the profession itself will suffer.

\title{
C. Investigating Corporations: No Easy Task Without Compelled Waiver
}

Investigating a corporation or a corporate crime is inherently more difficult than investigating an individual. "By its very nature, the criminal activity involved is much more complex than street crime, usually consisting of a number of events spread over an extended period of time, with the 'real' evidence frequently buried in reams of business and corporate records relating to numerous transactions. ${ }^{, 206}$ In the words of Deputy Attorney General Paul J. McNulty:

\begin{abstract}
In investigating wrongdoing by or within a corporation, a prosecutor is likely to encounter several obstacles resulting from the nature of the corporation itself. It will often be difficult to determine which individual took which action on behalf of the corporation. Lines of authority and responsibility may be shared among operating divisions or departments, and records and personnel may be spread throughout the United States or even among several countries. Where the criminal conduct continued over an extended period of time, the culpable or knowledgeable personnel may have been promoted, transferred, or fired, or they may have quit or retired. Accordingly, a corporation's cooperation may be critical in identifying the culprits and locating relevant evidence. ${ }^{207}$
\end{abstract}

An officer who is investigating a corporate crime must have access to a plethora of information just to understand the underpinnings of the transactions that ultimately culminated in the illegality. "The investigations require access to documents that detail the conduct of the transactions, especially the flow of funds and timing of decisions, and the statements of participants, both innocent and suspect, about the process of events." ${ }^{208}$

Even if investigators have access to all of the information within the corporation, the sheer volume of this information may make it extremely difficult for an investigator to zero in on the particular transactions that were involved in the crime. "Often the best witness is the defendant herself . . . in sorting out the paper trail and explaining the thought processes of the

206. Peter J. Henning, Testing the Limits of Investigating and Prosecuting White Collar Crime: How Far Will the Courts Allow Prosecutors to Go?, 54 U. PitT. L. Rev. 405, 408 (1993).

207. McNulty Memo, supra note 7, at VII.B.

208. Henning, supra note 206, at 408. 
defendants in pursuing a series of transactions." ${ }^{209}$ To the unfamiliar investigator, any of the transactions in the series may appear fairly benign. But the complexity of trying to piece them together may prevent the investigator from ever understanding what happened without someone providing a road map.

Investigators of corporate crimes can deal with these obstacles in a variety of ways. First, they could offer the corporation immunity in exchange for complete disclosure. This might be a beneficial approach if time is crucial to a public interest or if there is no other option. ${ }^{210}$ The obvious downside of this option is that it entirely forecloses the government's ability to prosecute the corporation. This could be particularly inappropriate "where the corporation's business is permeated with fraud or other crimes." 211 Second, the prosecutor could offer immunity to key employees and agents of the corporation in exchange for their cooperation. Of course, like offering immunity to the entire corporation, this could result in the most culpable corporate actors being immune from liability for their participation in the crime since, logically, the employees who will be in the best position to know what transpired are likely to be the employees who were most intimately involved in the crime. Third, the investigator could rely on the cooperation of other individuals within the organization who do not require immunity. Of the three options, this provides the best opportunity to get an inside perspective while avoiding giving immunity to culpable parties. The problem with this option is that these individuals may be unable to provide adequate assistance to the investigation. If they were not involved enough to require immunity, then they are unlikely to be able to provide investigators with any significant guidance regarding the heart of the illegality.

Thus, simple access to the information may not be enough to provide the investigators with the tools to understand the crime, and culling additional help from the parties involved may have significant downsides in the way of immunity or insufficiency. This means that the temptation to garner other forms of cooperation is particularly strong in a corporate criminal investigation. In the end, "the disclosure of privileged information may be critical in enabling the government to evaluate the accuracy and completeness of the company's voluntary disclosure." ${ }^{212}$ Any legislation prohibiting the use of compelled waiver must therefore provide a deterrence factor that will be

209. Id. at 449.

210. McNulty Memo, supra note 7, at VII.B.1.

211. $I d$.

212. Id. at VII.B.2. 
strong enough to overcome the prosecutor's temptation to obtain "critical" information in ways that the Attorney-Client Privilege Protection Act intends to prevent. The purposes of the Act must be supported by significant remedies and sanctions or an investigator could be tempted to seek to obtain the information anyway.

\section{Possible Remedies for Violation of the ACPPA ${ }^{213}$}

The ACPPA contains no guidance regarding the appropriate sanctions and remedies for a violation of the Act. If there is a violation, the courts will be forced to look to the common law to determine what sanctions and remedies would be appropriate. The possible sanctions and remedies that might apply include the following: an evidentiary exclusion of any information illegally obtained, dismissal of the indictment, or personal sanctions against the offending attorney. As discussed below, however, these sanctions and remedies are rarely imposed, may be inapplicable to the pre-indictment stage where the harm occurs, and may be inadequate to compensate a corporation for the violation of its rights. Furthermore, the lack of uniformity and certainty in application of these sanctions and remedies should prevent a corporation from putting too much faith in the protections of the ACPPA.

\section{A. Exclusion of Information Obtained}

The first potential remedy for a violation of the ACPPA is the exclusion of any information obtained by that violation from use at trial. Logically, exclusion of the information obtained is appropriate: since the government would not have had the information but for the waiver, it should not be allowed to use the illegally obtained information to its own benefit. "In other areas of criminal law and procedure, exclusion of evidence is often considered an appropriate remedy where the evidence has been obtained illegally or through a violation of the defendant's constitutional or statutory rights." 214

There are two significant problems, however, with expecting the application of this remedy to violations of the ACPPA. First, exclusion of evidence is only narrowly applied under the common law. ${ }^{215}$ As a general rule,

213. For a more thorough exploration of the effectiveness of remedies available for violation of the Act, see Sandra D. Jordan \& Jennifer Gardner, Does the Attorney Client Privilege Protection Act Actually Protect the Privilege?, 21 No. 12 White-Collar Crime Rep. 3, Sept. 12, 2007.

214. $I d$.

215. Id. at 4 . 
"a claim of outrageous government conduct premised upon deliberate intrusion into the attorney-client relationship will be cognizable where the defendant can point to actual and substantial prejudice." ${ }^{216}$ This strict standard will make it difficult for a corporation to obtain the exclusion of evidence once waiver has been compelled, illegally or not. Second, it is important to realize that "the exclusionary rule applies only at the defendant's criminal trial and not at ancillary civil proceedings." ${ }^{217}$ Coupled with the overall rejection of the doctrine of selective waiver, ${ }^{218}$ a corporation that has had its rights violated under the ACPPA will end up with very little protection for the information that is disclosed pursuant to an illegally obtained waiver. Neither the exclusionary rule nor the doctrine of selective waiver will prevent this information from being used against the corporation in civil matters.

\section{B. Dismissal of the Indictment}

Dismissal of the indictment is the remedy that is most likely to prevent an illegally compelled waiver from harming the corporation. Again, one needs only to look at the story of Arthur Andersen to see how harmful an indictment alone can be. ${ }^{219}$ Dismissing an indictment as early in the process as possible can minimize the harm to the corporation that might result from an indictment obtained by use of an illegally compelled waiver. A corporation should not have to face an indictment based solely on communications that it had with its attorneys. This is the heart of the attorney-client privilege.

Unfortunately, there are also significant problems with relying on the courts to apply this remedy in the absence of a provision in the ACPPA itself. For instance:

Under the common law, dismissal of an indictment is only permissible in limited circumstances. Essentially, it will only be dismissed if the prosecutor has violated certain of the defendant's constitutional rights, such as the Fifth Amendment right against self-incrimination, the right under the double-jeopardy clause not to be tried for the same crime or the right under the equal-protection clause not to be selectively prosecuted. ${ }^{20}$

216. United States v. Voigt, 89 F.3d 1050, 1066 (3d Cir. 1996). See also United States v. Haynes, 216 F.3d 789 (9th Cir. 2000).

217. Jordan \& Gardner, supra note 213, at 4 (citing United States v. Janis, 428 U.S. 433, 448 (1976)).

218. See supra Part. III.

219. See generally Ainslie, supra note 40. See also Jordan \& Gardner, supra note 213, at 4.

220. Jordan \& Gardner, supra note 213, at 4 (internal citations omitted). 
Additionally, in Bank of Nova Scotia v. United States, the United States Supreme Court held that "dismissal of the indictment is appropriate only 'if it is established that the violation substantially influenced the grand jury's decision to indict,' or if there is 'grave doubt' that the decision to indict was free from the substantial influence of such violations." 221 Like the standard for exclusion of the evidence, supra, this is a very difficult standard to satisfy. ${ }^{222}$

\section{Personal Sanctions}

In many cases, courts are also free to apply personal sanctions against an individual who violates a federal law. If an individual government official chooses to violate the ACPPA, that individual could be held personally liable for that decision. In a complicated and high profile corporate investigation, the temptation for an individual to cut corners in order to get the necessary information is significant. Therefore, it seems appropriate to have some mechanism to provide a personal deterrent against such behavior. Personal liability for the action seems to be an essential part of preventing an individual from succumbing to the temptation to obtain the much-needed information through violation of the ACPPA.

Since there are no specific sanctions provided by the ACPPA, and since the courts cannot invoke their contempt powers to order discretionary sanctions to matters that are not before the court, the only way that a government official will face personal sanctions is by way of a civil action against the government actor. Under 42 U.S.C. $\S 1983,{ }^{223}$ private individuals are able to bring a civil suit against a government actor if that actor violated any of the individual's "rights, privileges, or immunities secured by the Constitution and laws," while acting "under color of any statute . . of any State or territory or the District of Columbia." 224

However, $\S 1983$ actions are limited to claims against state government actors. ${ }^{225}$ Although the United States Supreme Court has created a similar claim for actions against federal government actors acting under federal law,

221. 487 U.S. 250, 256 (1988) (quoting United States v. Mechanik, 475 U.S. 66, 78 (1986) (O'Connor, J., concurring)).

222. See id. at 265 (Marshall, J., dissenting) (stating that the standard was so strict that it reduced the particular rule violated "to little more than a code of honor that prosecutors can violate with virtual impunity").

223. 42 U.S.C. $\S 1983$ (2006).

224. Id.

225. Bivens v. Six Unknown Named Agents of Fed. Bureau of Narcotics, 403 U.S. 388, 389 (1971). 
this cause of action has thus far only been allowed where the violation was a constitutional violation. ${ }^{226}$

In addition to the inapplicability of $\S 1983$ and the limited reach of a Bivens action, a corporation seeking to recover damages from a federal prosecutor would also have to overcome the protections of the qualified immunity doctrine. "In varying scope, a qualified immunity is available to officers of the executive branch of government, the variation being dependent upon the scope of discretion and responsibilities of the office and all the circumstances as they reasonably appeared at the time of the action on which liability is sought to be based." ${ }^{\prime 27}$ This qualified immunity is the same as that provided to officials under $\S 1983,{ }^{228}$ which extends immunity unless there was "some showing of malice" or "unless the constitutional right he was alleged to have violated was 'clearly established' at the time of the violation." ${ }^{229}$

\section{CONCLUSION}

Compelled waiver is a very real threat to the attorney-client privilege and the work-product protection doctrine. The evidence shows that the government systematically pursues waiver of these protections when it is investigating a corporation. Furthermore, recent testimony and official memoranda show that the Department of Justice has no interest in departing from this course of action: the Holder Memo, Mr. McCallum's remarks to the Sentencing Commission, and the McNulty Memo's recent minimal improvement to the Department of Justice policy demonstrate that the government is not going to self-regulate.

Although the doctrine of selective waiver has the potential to protect corporations from one adverse consequence of compelled waiver, it has been

226. See id. at 396-97 (allowing a claim against federal actors violating an individual's Fourth Amendment rights). See, e.g., Davis v. Passman, 442 U.S. 228, 228 (1979) (holding that a cause of action against a federal official could be sustained where the individual's Fifth Amendment rights were violated); Butz v. Economou, 438 U.S. 478, 486 \& n.8 (1978) (holding that "Bivens established that compensable injury to a constitutionally protected interest could be vindicated by a suit for damages invoking the general federal-question jurisdiction of the federal courts" but reserving the question of "what other personal interests were similarly protected by provisions of the Constitution"); Carlson v. Green, 446 U.S. 14, 18 (1980) (holding that Bivens allowed the victim of an Eighth Amendment violation to have a private cause of action against a federal agent).

227. Butz, 438 U.S. at 497 (internal citations omitted).

228. Id. at 500-01.

229. Id. at 498 . 
systematically rejected by nearly every court that has considered it, and it seems unlikely to be revived in the future. Even if selective waiver is revived, however, it does not go nearly far enough to protect corporations from the primary concern of compelled waiver. It gives corporations no protection from the primary harms that result when a corporation has no attorney-client privilege or work-product protection vis-à-vis the government. If anything, it encourages these waivers and further abrogates these protections versus the government.

The Attorney-Client Privilege Protection Act has the potential to be a powerful tool for preserving the attorney-client privilege and work-product protection, but corporations should still be aware of the temptation that prosecutors and investigators will have to obtain their confidential information in spite of the Act. A corporation should not rely on potential remedies and sanctions under the Act because it is unclear that any remedies or sanctions will actually be available in the event that a violation does arise. Instead, corporations should be on guard against potential pressures to waive their attorney-client privilege and work-product protections and should seek to actively protect these privileges rather than rely on the Act to do it for them. 